\title{
Nerve Sheath
}

National Cancer Institute

\section{Source}

National Cancer Institute. Nerve Sheath. NCI Thesaurus. Code C41439.

A protective cover encircling a nerve, nerve fiber or axon. 